\title{
Book-Tax Ratio and Earnings Quality of Listed Firms in Nigeria
}

\author{
Ferry Barineka Gberegbe \\ Kenule Beeson Saro-Wiwa Polytechnic, Bori, Rivers State
}

\begin{abstract}
The main objective of this study is to examine the nature relationship between book-tax ratio and earnings quality of listed firms in Nigeria. The other specific objective is to assess the level of earnings quality of listed firms in Nigeria. The expo facto design was adopted for this study on 47 listed firms on the Nigeria Stock Exchange. This design relies on secondary data in exploring the relationship between book-tax ratio and earnings quality. The result revealed that book-tax ratio has no significant positive association with earnings quality of listed firms in Nigeria. This suggests that taxable income does not convey additional incremental information on earnings with respect to contemporaneous stock returns and accruals. To the best of our knowledge, this is one of the few studies that have investigated the relationship between book-tax ratio and earnings quality in different sectors in Nigeria. The result has implication on capital market and earnings quality. Thus, the result of this study will be useful to capital market regulators, standard setters, and future researchers.
\end{abstract}

Keywords: earnings quality, tax accruals and taxable income

\section{Introduction}

The financial reporting system is designed to provide the basis of evaluating the current and future performance of a firm, and to provide accounting information that will be relevant to investors in asset pricing and investment decisions (Yuan \& Jiang, 2008). According to Velury and Jekins (2006), the usefulness of accounting information is manifested in its predictive powers and in the valuation of firm equity. Stable and predictable earnings are a desirable quality of accounting information that may have positive economic consequences on firm valuation and other contractual obligations. Analysts and market participants react to information content conveyed through accounting earnings. However, the financial reporting literature indicates that erosions in earnings quality have negatively influenced investor's confidence on the integrity of accounting information (Al-Dhamari, 2014). They use the publicly available information to ascertain the level of accuracy in the reported earnings.

The quality of accounting information is a summary measure of the financial statements that is associated with investment decisions, setting of standards, and other decisions because it shows the quality of earnings and investment efficiency. Accounting information provides investors, creditors, and managers with data that aid purchases, sales, and other financial obligations. It provides an accurate assessment of the probability distribution of future returns. However, high corporate failures (Xerox, Enron, Tyco, WorldCom, and Global crossing) in the past decades have increased the attention of scholars, investors, and policy-makers on earnings and how firm

Ferry Barineka Gberegbe, Department of Accountancy, Kenule Beeson Saro-Wiwa Polytechnic, Bori, Rivers State. 
earnings reflect economic reality and sustainable income (Lev \& Nissim, 2004). This shows the extent to which investors consider the earnings quality of listed firms (Landry \& Chlaka, 2005) and the question of the activities of managers. Similarly, in trying to identify the benchmark for earnings quality, scholars have drawn stakeholders' attention to the difference between reported earnings and taxable earnings that has increased during the early 1990's. How taxes influence earnings has raised serious academic interest (Shackelford \& Shevlin, 2001) and is assumed to provide important information about the quality of earnings (Petrick, 2001, Manson \& Plesko, 2002).

Managers compute two different versions of corporate income (Hanlon, 2005); accounting income based on the Generally Accepted Accounting Principles (GAAP) for shareholders' use (Dechow, 1994), and taxable income on the basis of tax rules and regulations for easy collection of tax revenue. Thus, the difference between accounting and taxable income arises from the choice of accounting policies and estimates, and tax laws (Landry \& Chlaka, 2005).

Accounting income is a major source of accounting information for market participants; however, Hanlon, Laplante, and Shirlin (2005) asserted that taxable income serves as an alternative source of accounting information about firm's underlying earnings process. Taxable income contains unique information about firm's current and future performance (Mayberry, McGuire, \& Omer, 2015). It recognizes earnings and expenses in different period relative to accounting; indicating that both measures contain unique accounting information about firm's experience.

In addition, Thomas and Zhang (2014) opined that tax expense is potentially informative to investors because it provides information about the underlying profitability of the firm and the information about how tax expenses are matched with pretax income recognized in the assessment period.

In Financial reporting, accounting (book) and tax are two independent measures of corporate performance (Shaviro, 2009) that are then assumed to be in conformity. Nevertheless, there is no consensus on the uniformity debate. According to Desai (2006), increasing accounting-tax conformity reduces opportunistic management behaviour, and encourages the monitoring and transparency of reporting. On the contrary, Shackelford (2006) argued that accounting-tax conformity will result to unnecessary interference by the relevant tax authorities, in the process of setting standards and may likely erode earnings quality. The difference between accounting and tax income are associated with manager's intention to mispresent earnings (Mills \& Newberry, 2001).

Taxable income conveys incremental information over accounting earnings with respect to contemporaneous stock returns (Shevlin, 2002) and can be used as a "reality check" for the quality of earnings (Lev \& Nissim, 2002). Corporate taxable income provides important macroeconomic statistics that can improve the decisions of investors and policymakers (Lev \& Nissim, 2004). Hanlon, Maydew, and Shevlin (2008) asserted that increasing the level of conformity between accounting earnings and taxable income is a way of strengthening the quality of earnings. According to Desai (2006), when conformity is weak, manager may act opportunistically by lowering for taxation and misleading other stakeholders. When the conformity between taxable income and accounting income is strong, the tax incentive to defer taxable income can lead to tax-induced conservatism (deferral of accounting income) (Guenther, Maydew, \& Nutter, 1997).

Guenther and Young (2000) claimed that accounting earnings may be less informative in reporting environments where there is strong linkage between tax and accounting. They furthered that if tax and accounting 
income must conform, accounting information may vary with the underlying economic activities because firms may want to pay less tax. Taxable income provides incremental information and it is not negatively influenced by cash flows (Lev \& Nissim, 2004). It excludes discretionary components of accruals (bad debts, warranty provisions, depreciation and amortization expenses, restructuring charges, impairment losses, etc.). Accordingly, when firms overstate earnings through discretionary accruals, taxable income will be lower than earnings and vice versa when there is understatement of earnings.

Cash flows and accruals have been established as indicators of earnings quality. Some studies (Hanlon, 2005; Lev \& Nissim, 2004) revealed that book tax difference is systematically associated with earnings persistence and stock returns. Desai (2006) reported that the dual system of reporting both book and taxable income gives allowance for creative decision making and may increase the provision for deferred tax liability (Revsine, Collins, \& Johnson, 2002). Lev and Nissim (2002) argued that taxable income provides information on earnings quality, particularly on the persistence of reported earnings and enhance the prediction of future earnings.

These suggest deteriorating earnings quality and a potential dangerous signal that Revsine et al. (2002) had ask for investigation.

There is empirical studies used taxable income measure to assess the quality of earnings in other countries. Hanlon et al. (2008) investigated the relationship between accounting earnings and taxable income in the US and reveal that increasing book-tax conformity has an unintended capital market consequences. Similarly, Choudhary, Koester, and Shevlin (2016) assessed the nature of association between firm characteristics and income tax accrual quality. They also revealed that tax accruals are associated with firm characteristics. Wysocki (2009) explored the properties and validity of earnings quality proxies derived from the Dechow and Dichev (DD, 2002) Model. The result indicates that the DD Model have significant limitations. Ayers, Jiang, and Laplante (2009) showed that the relative information content of estimated taxable income is significantly associated with stock returns. However, the association between earnings, stock returns, and taxable income is not the same because of the differences in the level of market efficiency. There is considerable variation in the operating environment and the level of economic development. Accounting standards are developed to satisfy the needs of capital markets and that differences in disclosure and measurement bring about cross-country differences in value relevance. The distributive statistics can be explained by capital market size, country characteristics, and the return window applied. Thus, the DD and Ohslon Models were used to explore the relationship between book-tax ratio and earnings quality of listed firms in Nigeria.

To our knowledge, there are limited studies that have examined the relationship between book-tax ratio and earnings quality in Nigeria, using taxable income. Thus, our result(s) provide additional explanation to earnings quality question(s).

Our paper proceeds as follows: Section 2 provides the statement problem of the study; the review of related literature in Section 3; methodology in Section 4; the results and discussion of findings in Section 5; conclusion in Section 6; and recommendations in Section 7.

\section{Statement of the Problem}

The extent to which taxable income contains information about earnings quality is yet to be determined in Nigeria. The preliminary evaluation of taxes indicates that corporate taxable income provides information that 
reflects reality and can improve the decision of investors and others. The excess of book income over taxable income might indicate deteriorating earnings quality and should be investigated. The difference between book and tax income are associated with manager's intention to manipulate earnings. In addition, the dual system of reporting both book and taxable income gives allowance for creative decision making. Hanlon (2005) claimed that book-tax temporary differences indicate the persistence of one-year ahead earnings. This has given researchers growing concern in Nigeria. Consequently, we need to investigate the relationship between book-tax ratio and earnings quality in Nigeria.

\section{Objective of the Study}

The main objective of this study is to examine the association between book-tax ratio and earnings quality of listed firms in Nigeria. Other specific objective is to assess the quality of listed firms in Nigeria.

\section{Research Question}

The study objectives will be addressed by the following question:

1. How does book-tax ratio associate with earnings quality of listed firms in Nigeria?

2. What is the level of earnings quality of listed firms in Nigeria?

\section{Hypothesis of the Study}

The following null hypotheses will be tested in the course of the study:

$\mathrm{H}_{\mathrm{O} 1}$ : Book-tax ratio has no significant influence on the earnings quality of listed firms in Nigeria.

\section{Literature Review}

In this section, the researchers examine related literature on the concepts, review of studies, and theory.

\section{Conceptual Review}

Earnings quality. Earning is an investment signal (Bender \& Nelson, 2013). Richardson (2003) defined earnings quality in terms of persistence and sustainability. Similarly, Bodie, Kane, and Marcus (2002) asserted that earnings quality should be sustained. From the above, we can deduce that earnings quality refers to the ability of reported earnings to reflect a firm's true earnings as well as its role in predicting future earnings.

It is the premium item of information provided in the financial statements that contains timely information that reflects the underlying changes in performance because of its matching attributes (Bepair, Rahman, \& Mollik, 2012). Earnings present a better indication of a firm's present and continuing ability to generate favourable cash flow from operation (CFO).

The financial reporting literature indicates that managers apply accounting policies that enable them to satisfy their interest by deferring the outcome of future periods in the current period. Therefore, managers may select accounting methods that enhanc earnings in the current period in order to avoid additional costs associated with debt obligations. Managers may use accounting methods that minimize earnings in order to reveal that the firm has suffered losses arising from unfair competition (Charfeddine, Riahi, \& Omri, 2013). Aljifri (2007) reported that managers exercise discretion over the opportunity of choosing accrual method within GAAP. By doing this, the quality of information available to others may be distorted such that the interested parties might not be able to examine the accuracy and reliability of the conclusions associated with reported earnings. 
Earnings quality measures. Different measures have been used to capture different dimensions of earnings quality. Scholars have developed several measures as proxies in measuring earnings quality. In some studies, discretionary accruals are used as proxy for earnings manipulation and interpreted as lowering earnings quality. On the other hand, others argue that discretionary accruals convey accounting information and should be positively associated with earnings quality.

In this study, we will consider an accounting based measure using accrual and market based measure using value relevance.

Tax accruals. According to Hribar and Collins (2002), accrual is the difference between an income statement and the associated cash flows. It is used to control the problems of timing differences created by evaluating the performance of firms in discrete periods. Accruals enable researchers to evaluate firm's economic performance, regardless of when cash flows occur. Thus, the mapping of accruals into related cash flows is a good measure of financial reports. Managers can use accruals to convey private information that will be useful to external stakeholders (Dechow, 1994), and minimize noise in the underlying cash flows and increasing the informativeness of earnings.

Tax accruals captures changes in the degree to which income tax maps into income tax-related cash flows (Choudhary et al., 2016), with lower variation indicating high tax accrual quality. It is influenced by GAAP-induced mismapping and estimation error. Estimation error arises from manager's inability to accurately forecast the tax implications of firm's operations. It occurs when personal judgement is applied, particularly in a complex reporting environment. Both GAAP-induced mismapping and estimation error can result to lower tax accrual quality (tax expenses do not reflect tax-related cash flows).

There are different incentives that will enable managers report book and tax income differently. Managers may report lower taxable income so as to pay less tax. On the other hand, managers may report higher book income in other to satisfy bond covenants, regulatory requirements and compensation contracts. However, there should be conformity between book and tax income. Accordingly, Hanlon et al. (2008) asserted that the level of conformity between book and tax income is a way of strengthening the quality of earnings. When the conformity between book and tax income is strong, the incentive to defer taxable income will be minimized (Guenther et al., 1997).

Value relevance. Value relevance (VR) is one of the basic attributes of accounting quality and capital market studies that is understood as the capacity of financial statements information to summarize information that influences the economic decision of the users by assisting the user in evaluating the past, present, and future events (Hellstrom, 2006). It indicates that the function of accounting information is to reflect economic income as expected by stock returns and economic value as shown in the market prices.

Beisland (2009) asserted that value relevance refers to the ability of accounting information to capture and summarize share price. This is collaborated by Kargih (2013) who referred value relevance as the ability of information disclosed in the financial statements to capture and summarize firm value. It is designed to assess the level to which accounting numbers represent information used in firm valuation and investment decisions.

Value relevance provides useful information (data on dividend and liabilities) to investors. It promotes greater openness and cooperation, better information disclosure, and building of trust in the society. However, the VR of earnings is conditional and depends on the financial reporting regime, economic condition, and 
institutional factors. Hellstrom (2006) asserted that the development of accounting regulation, control mechanisms, business climate change, internalization and business cycle, economic development, and industrial structure influence value relevance. The regulation, measurement, and valuation principles may influence the information in the financial statements that are used in decision making. These principles differ from one country to another; therefore, identifying the changes in accounting principles in a country is crucial to the understanding of their effects on value relevance.

The VR of accounting information can be evaluated from a signaling or measurement perspective. The signaling perspective provides means of assessing how stock reacts to the announcement of accounting information. Similarly, the measurement perspective explores the explicit relationship between market indicators of the value of the firm and accounting measures (Hellstrom, 2006). This was explored by Purswani and Anuradha (2017), which revealed that earnings per share and value per share have positive significant relationship with share price of Bombay listed construction firms.

\section{Empirical Review}

Although tax measure has been identified as more informative than other earnings quality measures, there are limited studies that investigate the association between stock price, taxable income, and earnings, particularly in developing capital markets. The results of some of the existing studies are enumerated below.

Lev and Nissim (2002) investigated the information gap between reported and taxable income, and earnings quality. Using 79,642 firm-years observation on US firms, they document that the ratio of taxable-to-reported income is positively correlated with earnings persistence, accruals, and cash flows. In another study, Lev and Nissim (2004) examined the relationship between taxable income, equity values, and earnings. Using a sample of 40, 372 US firm-years observation, the regressed result reveal that tax-to-book income ratio predicts subsequent five-year changes in earnings. They also revealed that taxable income information about future earnings is incremental to accruals and cash flows. Based on the findings, they recommended for a comprehensive analysis of the costs of disclosures on the integrity of tax compliance of firms.

Chen, Dhaliwal, and Trombley (2007) explored the effect of tax planning and earnings management on the relative informativeness of book income and taxable income. Using 60,636 firm-year observations over the period (1993-2005), the regressed result indicates that voluntary book-tax conformity is positively associated with the relative informativeness of book and taxable income. In addition, they found that high tax planning firms have relatively less informative taxable income than low tax planning firms and less earnings quality firms have less informative book income. Finally, the result indicates that the informativeness of book income is reduced by aggressive tax planning.

Hanlon et al. (2008) assessed the association between accounting earnings and taxable income. The result from a sample of 56 US firms shows that increasing book-tax conformity has an unintended capital market consequences. Also, they reveal that increase in book-tax conformity is negatively associated with informativeness of accounting earnings. They concluded that the behavioural response to an increase in book-tax conformity will result in less informative earnings that will be reported to other stakeholders.

Using a sample of 1,703 US firms, Wysocki (2009) explored the properties and validity of earnings quality proxies derived from the DD (2002) Model. The result shows that the DD Model has significant limitations, and 
does not appear to reliably capture high accruals quality. The researcher demonstrates a strong negative contemporaneous correlation between accruals and cash flows from operations.

Ayers et al. (2009) investigated the nature of association between tax planning, taxable income, and earnings quality, using a 50,760 firm-year observations. They reported that the relative information content of estimated taxable income for high tax planning firms is much lower than that of other firms. The result indicates that estimated taxable income is significantly associated with stock returns. They show that taxable income measure is important in reporting environment where managers have more discretion in reporting book income. Finally, they document that tax planning and low earnings quality proxies are likely to detect earnings where book-tax differences are more attributable to discretionary book or taxable income.

Alwood, Drake, and Myers (2010) explored the association between book-tax conformity, earnings persistence, and the association between earnings and future cash flows. Using a 125,859 firm observations from 33 countries, they show that increased book-tax conformity reduces earnings quality. Baez-Diaz and Alam (2013) investigated the association between tax conformity of earnings and the pricing of accruals. Using a sample of 6,397 firms and Mishkin Model, they show that the over pricing of tax accruals is more severe than that for accounting accruals.

Al-Dhamari (2014) evaluated the association between board characteristics and earnings quality. Using heteroskedastility-correlated least square regression on a sample of 330 Malaysian firms. The result indicates that investors do not perceive board size as a good indicator of earnings quality. Blaylock, Gaertner, and Shevlin (2015) examined the relationship between book-tax conformity and earnings management. Using a sample of 139,536 firm-year observations of US firms, across 34 countries, they found that higher book-tax conformity is associated with earnings management.

Choudhary et al. (2016) investigated the nature of relationship between firm characteristics and income tax accrual quality. Using a sample of 12,861 firm-year observations they show that tax accrual quality is associated with firm's characteristics. They revealed that tax accrual is crucial to capital markets and is empirically different from working capital accruals quality. Based on the result, they recommended for the use of tax accrual quality in estimating the error in income tax account.

\section{Theoretical Framework}

We will explain the theory associated with our study in this section.

Agency theory. Although there are several theories that are linked with financial reporting, we adopt agency theory (AT) in our work. Agency theory is the dominant theory that is linked with different aspects of earning. It is based on the work of modern corporation and property on the separation of company ownership from the management. This theory is credited to the theory of the firm: managerial behaviour, agency costs and ownership structure. The proponents argue that agency problems will always emanate in circumstances where the owners and shareholders employ the board and management to act on their behalf for a reward.

Financial reporting quality is used to minimize adverse selection and moral hazard problem that are attributable to information asymmetry and agency conflict. The conflict of interest between managers and other stakeholders in a diffused ownership supports the demand for corporate disclosure that assists in minimizing information asymmetry. It is assumed that AT is used to explain the conflict between the controlling agent 
(managers) and the principal (shareholders). Agency theory is a tool that distinguished the opportunistic and beneficial user of earnings management.

\section{Methodology}

Ex-post facto design was used in conducting this study. This design relies on previously generated data that was used in exploring the relationship between book-tax ratio and earnings quality of listed firms in Nigeria. This study population consists of all listed firms, 176, that have traded on the Nigerian Stock Exchange (NSE) between 2005-2015. The stratified random sampling (probabilistic sampling technique) and purposive techniques was used in selecting of sample size of 47.

The data for this study were obtained from NSE. Descriptive content analysis was adopted in extracting the required data from the audited annual reports of the selected firms. These data were analysed using descriptive statistics (mean, minimum, maximum, and standard deviation). The descriptive statistics was used in data analysis so as to have a general description of the research variables in terms of the location and the dispersion of the data for each of the variable. Shapiro-Wilk test of normality was used to test the normality of the data. Multiple regressions were used to obtain the proxy for earnings quality based on Ohlson's and DD Models. This was done for each of the firm considered in the study. Also, to test the hypotheses, the linear regression was used.

Breusch-Pagan-Godfrey test for used to check the assumptions of homoscedasticity of the residuals. These two assumptions were tested so as to determine whether the multiple regression Models satisfy its underlying assumption with regards to multicollinearity and homoscedasticity of the errors. To facilitate data analysis, the Statistical Package for Social Science (SPSS) used. The hypothesis was tested at the 0.05 level of significance.

To test the hypothesis, the working capital was regressed against $\mathrm{CFO}_{\mathrm{t}-1}, \mathrm{CFO}_{\mathrm{t}}$, and $\mathrm{CFO}_{\mathrm{t}+1}$ to derive the error term for accrual measure. Similarly, the price per share was regressed against the earnings per share and book value per share to derive the error term for value relevance. Finally, the coefficient of the book-tax ratio was regressed against the error terms.

\section{Measurement of Dependent Variable}

The dependent variable for this study is earnings quality which was measured using DD Model and Ohlson Model. This is explained below.

Dechow \& Dichev (2002) modeled accruals as function of past, present, and future cash flows given their purpose to alter the timing of cash flow recognition in earnings. It is estimated from the regressing of the differences between changes in working capital and cash from operations in the past period, current period, and future period, and using the unexplained portion of the differences as a measure of earnings quality.

Where $\mathrm{EQ}=$ Earnings quality measured by the value of the error term.

$\Delta \mathrm{WC}=\alpha_{0}+\alpha_{1} \mathrm{CFO}_{\mathrm{t}-1}+\alpha_{2} \mathrm{CFO}_{\mathrm{t}}+\alpha_{3} \mathrm{CFO}_{\mathrm{t}+1}+\varepsilon_{t}$. Making $\varepsilon_{t}$ the subject in Equation 6, we have; $\varepsilon_{t}=\Delta W C_{t}-\left(b_{0}+b_{1} C F 0_{t-1}+b_{2} C F 0_{t}+b_{3} C F 0_{t+1}\right)$.

Where $\Delta \mathrm{WC}=$ Change in working capital; $\mathrm{CFO}_{\mathrm{t}-1}=$ Cash flows at the start; $\mathrm{CFO}_{\mathrm{t}}=$ Current cash flows; $\mathrm{CFO}_{\mathrm{t}+1}=$ Cash flows at the end and $\varepsilon=$ estimated error associated with accruals. The estimator error indirectly measures the extent to which accruals map into cash realization. $\Upsilon_{0}=$ Intercepts and $\alpha_{1}, \alpha_{2}$, and $\alpha_{3}$ are estimated coefficients from year $(t-1)$ to $t+1$. All items are lagged by total assets. Theoretically, the coefficients are expected to give the values $0<\alpha_{1}, 1,-1<\alpha_{2}$, and $0<\alpha_{3}<1$. 
Value relevance is the explanatory power of accounting variables for stock. The explanatory power of regression $\left(R^{2}\right)$ is used as the metric to measure the value relevance of earnings and book value. The proponents argue that Ohlson Model is the best model of value relevance aimed at relating the firm market value, earnings, and book value. It explains how stock prices could be examined using corporate financial, sectoral, and macroeconomic factors. The market value of a stock is explained by its book value per share and earnings quality. It allows the derivation of closed firm expression relating to market value to accounting data and other information.

Ohlson (1995) models value relevance as follows:

$P_{i t}=\alpha_{0}+\alpha_{1} \mathrm{EPS}_{\mathrm{i}, \mathrm{t}}+\alpha_{2} \mathrm{BVPS}_{\mathrm{i}, \mathrm{t}}+\varepsilon_{i, t}$

Where $P_{i t}$ is the price of a share at the end of each year for firm $i$ and time $t, E P S_{i, t}$ is the earnings per share before extra ordinary items for firm $i$ and period $t$., $B V P S_{i, t}$ is the book value of equity per share for firm $i$ and time $t, \varepsilon_{i, t}$ is random error term with mean 0 and variance 1 , and $\alpha$ represents regression coefficient.

\section{Results}

Table 1 shows that that book-tax ratio accounted for $0.2 \%$ of the variation in earnings quality of listed firms in Nigeria. The result also reveals standardized beta of -0.153 , which means that for every one unit increase in book-tax ratio, earnings quality will decrease by 0.153 . The $t$-calculated of 0.912 against its $t$-critical of 1.97 at 0.05 level of significance. The $t$-calculated (1.039) is less than the $t$-critical of 12.01 at 0.05 level of significance. It reveals that the $F$-calculated (1.080) is less than the $F$-critical (4.06) at the 0.05 level of significance. This result suggests that there no significant relationship between book-tax ratio and earnings quality. Thus, null hypothesis which states that book-tax ratio does not significantly influence earnings quality of listed firms in Nigeria.

Table 1

Summary Result of the Relationship Between Book-Tax Ratio and Earnings Quality of Listed Firms in Nigeria, Using Ohlson's Model

\begin{tabular}{llllll}
\hline & $\mathrm{B}_{1}$ & $\mathrm{SE}$ & $\mathrm{B}_{2}$ & $t$-value & $p$-value (2 tailed) \\
\hline Constant & 0.478 & 0.067 & & 7.112 & 0.000 \\
Book tax income & -0.080 & 0.077 & -0.153 & -1.039 & 0.304 \\
\hline
\end{tabular}

Dependent variable: Earnings quality based on Ohlson Model

$R=0.153$

Adjusted $R$-square $=0.002$

Std. Error of estimate $=0.27187630$

$F$-calc. $=1.080$

F-critic. $=4.06$

Notes. "Significantly related at $5 \%(p<0.05)$. $t$-critical $=2.01, B_{1}=$ unstandardized beta, $B_{2}=$ standardized beta, $\mathrm{SE}=$ standard error. Source: Authors' computation, 2017.

Table 2 reveals that $0.4 \%$ of the variation in earnings quality was accounted for by book-tax ratio. The standardized beta of 0.063 reveals that for every 1 unit increase in book tax ratio, earnings quality will increase by 0.063 . The $t$-calculated $(0.424)$ was obtained against its $t$-critical of 2.01 at 0.05 level of significance. The result also yielded F-calculated of 0.180 which is less than F-critical of 4.06 at the 0.05 level of significance. The $t$-calculated (0.424) is less than the $t$-critical (2.01) at 0.05 level of significance. Hence, we show that book-tax ratio does not significantly influence earnings quality of listed firms in Nigeria. 
Table 2

Summary Result of the Relationship Between Book-Tax Ratio and Earnings Quality of Listed Firms in Nigeria, Using DD Model

\begin{tabular}{llllll}
\hline & $\mathrm{B}_{1}$ & $\mathrm{SE}$ & $\mathrm{B}_{2}$ & $t$-value & $p$-value (2 tailed) \\
\hline Constant & 0.139 & 0.017 & & 8.164 & 0.000 \\
Book tax income & 0.008 & 0.019 & 0.063 & 0.424 & 0.674 \\
\hline
\end{tabular}

Dependent variable: Earnings quality based on Ohlson Model

$R=0.063$

Adjusted $R$-square $=0.004$

Std. Error of estimate $=0.068755915$

$F$-calc. $=0.180$

F-critic. $=4.06$

Notes. " Significantly related at $5 \%(p<0.05)$. t-critical $=2.01, \mathrm{~B}_{1}=$ unstandardized beta, $\mathrm{B}_{2}=$ standardized beta, $\mathrm{SE}=$ standard error.

Source: Authors' computation, 2017.

\section{Summary of Findings}

From the result of the data analysis, the following findings were made:

(1) The earnings quality of firms varies from one sector to another.

(2) This study showed that the result of accounting based and market based measures of earnings quality is not the same.

(3) The result indicates that book-tax ratio has no significant positive influence on earnings quality of listed firms in Nigeria.

\section{Conclusion}

This study investigated the association between book-tax ratio and earnings quality of listed firms in Nigeria. The researcher used data obtained from 47 listed firms in Nigeria for 11 years (2005-2015). Descriptive and inferential statistical analyses were conducted on the data in addressing the research objective, question, and hypothesis.

The measure of earnings quality is based on the Ohlson Model and the accrual quality metric developed by Dechow and Dichev (2002), referred to as the DD Model. The result showed that earnings quality vary among firms when the two models were used.

The results showed that book-tax ratio has no significant positive influence on earnings quality of listed firms in Nigeria. This is contrary to the claim that the ratio of taxable-to-reported income is positively correlated with cashflows and market price. It implies that taxable income does not provide incremental information on earnings quality in Nigeria. This statistics can be explained by differences in the size of the capital market, country characteristics, and the return window applied.

\section{Recommendation}

Based on the findings, we recommend that book-tax ratio should not be used to assess earnings quality of listed firms in Nigeria. In addition, other measures of earnings quality is recommended for related studies by other researchers. In addition, we suggest that similar study should be conducted beyond the scope of our study. 


\section{References}

Aljifri, K. (2007). Measurement and motivations of earnings management: A critical perspective. Journal of Accounting-Business and Management, 14, 75-95.

Al-Dhamari, A. R. (2014). Association between board characteristics and earnings quality: Malaysia evidence. Journal Pengurusan, 41, 43-55.

Atwood, J. T., Drake, S. M., \& Myers, A. L. (2010). Book-tax conformity, earnings persistence and the association between earnings and future cash flows. Journal of Accounting and Economics, 50, 111-125.

Ayers, C. B., Jiang, X. J., \& Laplante, K. S. (2009). Taxable income as a performance measure: The effects of tax planning and earnings quality. Contemporary Accounting Research, 26(1), 15-54.

Baez-Diaz, A., \& Alam, P. (2013). Tax conformity of earnings and the pricing of accruals. Review of Quantitative Finance and Accounting, 40, 509-538.

Beisland, L. A. (2009). A review of the value relevance literature. The Open Business Journal, 2, 7-27.

Bender, J., \& Nelsen, F. (2013). Earnings quality revisited. The Journal of Portfolio Management, 39(4), 69-79.

Bepari, K. M., Rahman, F. S., \& Mollik, T. A. (2012). Value relevance of earnings and cash flows during the global financial crisis. Review of Accounting and Finance, 12(3), 226-251.

Blaylock, B., Gaertner, F., \& Shevlin, T. (2015). The association between book-tax conformity and earnings management. Review of Accounting Studies, 20, 141-172.

Bodie, Z., Kane, A., \& Marcus, J. (2002). Investment (6th ed.). New York, NY: Mc Graw-Hill.

Charfeddine, L., Riahi, R., \& Omri, A. (2013). The determinants of earnings management in developing countries: A study in the Tunisian context. Journal of Corporate Governance, 12(1), 35-49.

Chen, H. L., Dhaliwal, S. D., \& Trombley, A. M. (2007). The impact of earnings management and tax planning on the information context of earnings. Retrieved from https://papers.ssrn.com/sol3/papers.cfm?abstract_id=1028808

Choudhary, P., Koester, A., \& Shevlin, T. (2016). Measuring income tax accrual quality. Revenue Account Studies, 21, 89-139.

Desai, M. (2006). Testimony of Mihir Desai associate professor, Howard University, before the sub-committee on Select Revenue Measures Committee on ways and means, House of Representative.

Guenther, D; Maydew, E., \& Nutter, S. (1997). Financial reporting, tax costs, and book-tax conformity. Journal of Accounting and Economics, 23(3), 230-243.

Guenther, M., \& Young, D. (2002). The association between financial accounting measures and real economic activity: A multinational study. Journal of Accounting and Economics, 1(1), 53-72.

Hanlon, M., \& Shevlin, T. (2003). What can we infer about a firm's taxable income from its financial statements? National Tax Journal, 56(4), 831-864.

Hanlon, M. (2005). The persistence and pricing of earnings, accruals and cash flows when firms have large book tax differences. The Accounting Review, 80(1), 137-166.

Hanlon, M., Maydew, L. E., \& Shevlin, T. (2008). An unintended consequences of book-tax conformity: A loss of earnings informativeness. Journal of Accounting and Economics, 46, 294-311.

Hellstrom, K. (2006). The value relevance of financial accounting information in a transition economy: The case of the Czech Republic. European Accounting Review, 15(3), 325-349.

Hribar, P., \& Collins, D (2002). Errors in estimating accruals: Implications for empirical research. Journal of Accounting Research, 40, 105-134.

Kargin, S. (2013). The impact of IFRS on the value relevance of accounting information: Evidence from Turkish Firms. International Journal of Economics and Finance, 5(4), 71-87.

Landry, S., \& Chloka, N. (2005). Taxable income and analysis. Camagazine, 51-54.

Lev, B., \& Nissim, D. (2002). Taxable income as an indicator of earnings quality. Retrieved from https://pdfs.semanticscholar.org/7197/8b6e3156ecfca2d052fa2f4c56bff89c1414.pdf

Lev, B., \& Nissim, D. (2004). Taxable income, future earnings and equity values. The Accounting Review, 79(4), 1039-1074.

Manson, G. B., \& Plesko, G. A. (2002). The relation between financial and tax reporting measures of income. The Law Review, 55, $175-214$.

Mayberry, A. M., McGuire, T. S., \& Omer, C. T. (2015). Smoothness and the value relevance of taxable income. The Journal of the American Taxation Association, 37(2), 141-167. 
Mills, L., \& Newberry, K. (2001). The influence of tax and non-tax costs on book-tax reporting differences: Public and private firms, Journal of the American Taxation, 23, 1-19.

Patrick, K. A. (2001). Comparing NIPA profits with S \& P 500 Profits. Survey of Current Business. Retrieved from http://webapp1.dlib.indiana.edu/virtual_disk_library/index.cgi/4298367/FID900/articles/0401scb.pdf

Purswani, G., \& Anuradha, P. S. (2017) Value relevance of accounting information: An empirical study on construction companies listed on Bombay Stock Exchange. Journal of Accounting Research and Audit Practice, 14(2), 34-42.

Ragab, A. A., \& Omran, M. M. (2006). Accounting information, value relevance and investors' behaviour in the Egyptian equity market. Review of Accounting and Finance, 5(3), 279-297.

Revsine, L., Collins, D., \& Johnson, B. (2002). Financial reporting and analysis. Upper Saddle River: Prentice Hall.

Revsine, L., Collins, W. D., \& Johnson, B. W. (1999). Financial reporting and analysis. Upper Saddle River, N J.

Richardson, S. (2003). Earnings quality and short sellers. Accounting Horizons. Retrieved from https://ssrn.com/abstract=410382

Shackelford, D., \& Shevlin, T. (2001) Empirical tax research in accounting. Journal of Accounting and Economics, 31, $321-387$.

Shackelford, D. (2006). Testimony before the subcommittee on select revenue measures of the House Committee on ways and means. Retrieved from http://waysandmeans.house.gov/hearings.asp?formmode=view\&id=144

Shaviro, D. (2009). Internationalization of income measures and the US book-tax relationship. National Tax Journal, 42(1), 155-167.

Shevlin, I. (2002). Corporate tax shelters and book-tax differences. The Law Review, 55, 427-443.

Thomas, J. K., \& Zhang, F. (2014). Valuation of tax expense. Review of Accounting Studies, 19(4), 1436-1467.

Velery, U., \& Jekins, D. S. (2006). Institutional ownership and the quality of earnings. Journal of Business Research, 59(9), 1043-1051.

Wysocki, D. P. (2009). Assessing earnings and accruals quality: US and International evidence. Retrieved from https://pdfs.semanticscholar.org/2267/35454d75de3be5a91efe6445a7964822aa58.pdf

Yuan, J., \& Jiang, Y. (2008). Accounting information quality, free cash flow and over investment: A Chinese study. The Business Review, Cambridge, 11(1), 59. 